\title{
Thể hiện lòng yêu nước bằng việc làm cụ thể
}

Thứ Sáu, 29-08-2014, 03:40

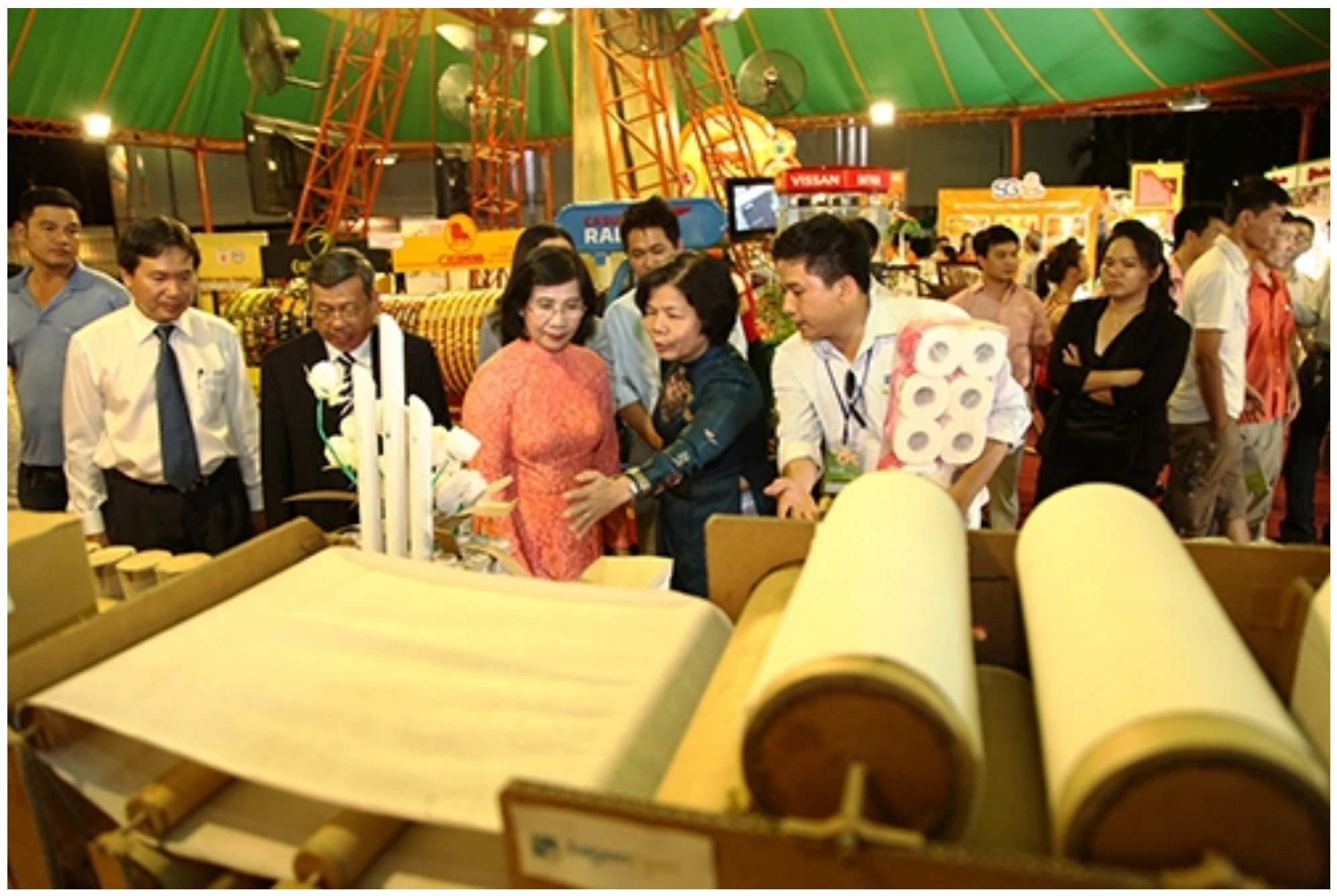

Lãnh đạo TP Hồ Chí Minh tham quan mô hình Nhà máy giấy Sài Gòn tại Ngôi nhà Triển lãm Đổi mới sáng tạo, Hội chợ Hàng Việt Nam chất lượng cao TP Hồ Chí Minh 2014.

Lòng yêu nước có thể tạo nên giá trị gia tăng cho mỗi sản phẩm Việt trong lựa chọn của người tiêu dùng. Nhưng để cạnh tranh với các thương hiệu nước ngoài, doanh nghiệp cần nhiều hơn thế, bà Vũ Kim Hạnh- Chủ tịch Hội Doanh nghiệp hàng Việt Nam chất lượng cao, chia sẻ những trăn trở về đường đi còn lắm gian nan của Thương hiệu Việt trong bối cảnh hội nhập ngày một sâu rộng.

1 Mục tiêu của cuộc vận động "Người Việt Nam ưu tiên dùng hàng Việt Nam" chính là kêu gọi lòng yêu nước một cách thiết thực đối với cả bốn thành phần liên quan đến vòng đời của một thương hiệu Việt: nhà sản xuất, người tiêu dùng, Nhà nước, nhà truyền thông và xúc tiến. 
Nhìn lại kết quả 5 năm cuộc vận động không thể chỉ nhìn xem nhà sản xuất và người tiêu dùng yêu nước đến độ nào mà còn phải nhìn đến chính sách của Nhà nước hỗ trợ đến đâu, từ yếu tố tạo điều kiện cho doanh nghiệp phát triển đến quản lý thị trường và đầu tư cho tiêu dùng hàng Việt ra sao. Tôi biết có phong trào "dừng lại 30 giây" trong Việt kiều ở Mỹ, thể hiện lời kêu gọi từ chính trong cộng đồng là khi đến siêu thị, định mua một món hàng nào thì hãy dừng lại chỉ 30 giây, nghĩ xem mặt hàng này Việt Nam có chưa, có bán tại siêu thị không để nếu có thì nên ủng hộ cho hàng Việt. Họ truyền tai nhau, mua một sản phẩm Việt Nam là có thêm một việc làm cho người lao động ở quê nhà. Nhưng, người tiêu dùng không yêu hàng Việt một cách vô điều kiện, mà họ đòi hỏi nghiêm khắc.

Thực tế cho thấy, khách (các thương hiệu quốc tế sản xuất ở Việt Nam), với kỹ thuật nghiên cứu thị trường, tính chuyên nghiệp cao và ngân sách "khủng" về marketing, phân phối đang chiếm thị phần lớn trên thị trường. Chủ nhà không đủ lực để theo đuổi cuộc đua tấn công vào tâm trí, thói quen, hành vi người tiêu dùng. Nhưng các doanh nghiệp trong nước không buông tay chấp nhận thua cuộc. Trong khuôn khổ chương trình "Hỗ trợ doanh nghiệp về Đổi mới sáng tạo" do Hội Doanh nghiệp hàng Việt Nam chất lượng cao phối hợp với Bộ Khoa học -Công nghệ tổ chức, khi sử dụng bộ đo mới i2Metrix để khảo sát và tư vấn cho doanh nghiệp về nâng cao năng lực cạnh tranh, chúng tôi cảm động nhận ra nhiều cố gắng bền bỉ của doanh nghiệp trong nước. Họ chọn con đường không ngừng đổi mới sáng tạo trong cải tiến dây chuyền, quy trình công nghệ, quản trị. Cơ hội thị trường chính là nguồn động viên lớn. ứng biến nhanh, không ngừng thay đổi để chinh phục người tiêu dùng, hiện nay, lớp trẻ kế thừa trong quản trị các doanh nghiệp dẫn đầu đang là những người có cảm nhận nhanh nhất, tinh tế nhất các cơ hội thị trường và lại đủ năng lực tổ chức cuộc cạnh tranh. Chính các bạn trẻ thắp lên trong chúng ta một niềm tin ở tương lai.

2 Doanh nghiệp Việt sức còn mỏng, lực còn yếu, đã vậy tinh thần liên kết cũng chưa cao. Trên toàn chuỗi giá trị làm nên sản phẩm, nếu xem xét kỹ từng khâu, chúng ta đều thấy những mặt cần cải tiến và nâng lên: ý tưởng sản phẩm, thiết kế, chọn công nghệ, thiết bị, quy trình, quản trị sản xuất, tiếp thị, xây dựng thương hiệu, phân phối, khâu nào cũng đòi hỏi chuyên nghiệp, hiệu quả. Theo tôi, điểm yếu về nguồn lực của doanh nghiệp cần được chú trọng phân tích kỹ để khắc phục. Chính sách và môi trường kinh doanh cần được xây dựng nhằm tạo nền và hỗ trợ doanh nghiệp trong cuộc cạnh tranh ngày càng khốc liệt. Thế nhưng, chưa có cơ quan quản lý nhà nước nào nhìn nhận, tổng kết 5 năm cuộc vận động "Người Việt Nam ưu tiên dùng hàng Việt Nam" là dịp để ngồi lại đối thoại thật căn cơ với các doanh nghiệp xem họ đang cần gì, đang thiết tha mong mỏi gì nơi chính sách đầu tư - hỗ trợ cho doanh nghiệp của Nhà nước? Muốn thúc đẩy hàng Việt cạnh tranh tốt hơn trên chặng đường mới đầy thách thức - thực hiện cộng đồng kinh tế chung của ASEAN vào năm 2015, ngoài việc đánh thức tình yêu nước trong mỗi người dân còn cần đến những động thái chính sách rõ ràng, nhất quán. 


\section{f $\quad 0 \quad \square \quad$ Quan tâm}


